\title{
Proteinase PrtP impairs lactococcin LcnB activity in Lactococcus lactis BGMN1-501: new insights into bacteriocin regulation
}

\section{Goran Vukotic ${ }^{1,2+}$, Nemanja Mirkovic ${ }^{1,3+}$, Branko Jovcic ${ }^{1,2}$, Marija Miljkovic ${ }^{1}$, Ivana Strahinic ${ }^{1}$, Djordje Fira ${ }^{1,2}$, Zorica Radulovic ${ }^{3}$ and Milan Kojic ${ }^{1}$ *}

${ }^{1}$ Laboratory for Molecular Microbiology, Institute of Molecular Genetics and Genetic Engineering, University of Belgrade, Belgrade, Serbia

${ }^{2}$ Chair of Biochemistry and Molecular Biology, Faculty of Biology, University of Belgrade, Belgrade, Serbia

${ }^{3}$ Department for Food Microbiology, Faculty of Agriculture, University of Belgrade, Belgrade, Serbia

\section{Edited by:}

Javier Carballo, University of Vigo,

Spain

\section{Reviewed by:}

Qiaobin Xiao, University of Notre Dame, USA

Learn-Han Lee, Monash University Malaysia, Malaysia

\section{*Correspondence:}

Milan Kojic, Laboratory for Molecular Microbiology, Institute of Molecular Genetics and Genetic Engineering, University of Belgrade, Vojvode Stepe 444a, Belgrade 11010, Serbia

e-mail:mkojic@imgge.bg.ac.rs

${ }^{t}$ These authors have contributed equally to this work.

\begin{abstract}
Proteinases and bacteriocins are of great importance to the dairy industry, but their interactions have not been studied so far. Lactococcus lactis subsp. lactis BGMN1-5 is a natural isolate from homemade semi-hard cheese which produces two bacteriocins (Lactococcin B and LsbB), as well as proteinase PrtP. A medium-dependent increase in the bacteriocin LcnB activity of L. lactis BGMN1-501, a derivate of L. lactis subsp. lactis BGMN1-5, was shown to be accompanied by a decrease in its promoter activity. A similar effect of media components on gene expression was reported for proteinase PrtP, whose gene is co-localized on the same plasmid as the $I c n B$ gene. Thus, the PrtP-LcnB interplay was investigated. Single gene knockout mutants were constructed with disrupted prtP or I $\mathrm{cn} B$ genes. PrtP- mutants showed higher bacteriocin activity that had lost its growth medium dependence, which was in contrast to the original strain. When LcnB from this mutant was combined with proteinase from the $\mathrm{LcnB}^{-}$mutant in vitro, its activity was rendered to the original level, suggesting that proteinase reduces bacteriocin activity. We propose a new model of medium dependent expression of these genes with regard to the effects of their interaction in vivo.
\end{abstract}

Keywords: lactococci, bacteriocin activity, LcnB, proteinase PrtP, digestion, medium dependent activity

\section{INTRODUCTION}

Lactococcus lactis is the best characterized species of lactic acid bacteria (LAB) and one of the most studied and utilized Grampositive bacteria. It is used as a starter culture for manufacturing a wide variety of fermented milk products, either as a single culture or in a mixture with other LAB. It's most important trait is the production of lactic acid and the acidification of milk, which is used in numerous ways in the production of fermented milk products. It leads to curdling of milk and at the same time prevents the growth of undesirable bacteria. Among other prominent and well-known features of lactococci is the production of proteolytic enzymes and a diverse array of bacteriocins (Lahtinen et al., 2012).

Proteinases, as part of a complex proteolytic system, confer on lactococci the ability to multiply quickly in milk, which is of great importance for the dairy industry. Furthermore, proteinases are involved in the development of organoleptic properties in fermented milk products and their activity may affect consumers' health, especially regarding the activity of peptides, which they release from milk proteins. Diverse bioactive peptides liberated by milk proteolysis have been described as having immunomodulatory, antioxidative, antihypertensive, and antimicrobial properties (Hayes et al., 2007). The occurrence and composition of bioactive peptides depend mainly on the substrate specificity of proteinases applied in food processing.

Numerous lactococci produce bacteriocins, ribosomally synthesized antimicrobial peptides, which can vary widely in structure and mode of action. This diversity has led to the division of bacteriocins into several classes with multiple subclasses (Cotter, 2014). Bacteriocins are very important for colonization and survival in niches such as milk or cheese. In such highly competitive conditions they provide an advantage over closely related species, which are generally their main targets. Nevertheless, some bacteriocins are active against a wide variety of pathogens, either Gram-positive or Gram-negative, which is why they have been widely applied in food preservation and are very important in the search for new antibiotics. Besides these bactericidal effects, bacteriocins can also serve as signaling molecules, enabling bacterial communication, and coordination through quorum sensing. In addition, this bacteriocin-driven communication can also take place between different bacterial species (Calasso et al., 2013), as well as between host immune cells and colonizing bacteria (Meijerink and Wells, 2010; van Hemert et al., 2010).

Lactococcus lactis subsp. lactis BGMN1-5 is a natural isolate from homemade semi-hard cheese which produces two potent bacteriocins [Lactococcin B ( $\mathrm{LcnB}$ ) and LsbB] and proteinase PrtP (Gajic et al., 1999). Its derivate, L. lactis subsp. lactis BGMN1-501, obtained by plasmid curing, retained genes for LcnB and proteinase PrtP, which colocalize on the same plasmid, pMN80 (Kojic et al., 2006). PrtP is a large ( $200 \mathrm{kDa})$ extracellular enzyme that is attached to the cell wall at its $\mathrm{C}$ terminus, although autocatalytically truncated active molecules are abundant in the extracellular environment (Laan and Konings, 1989). LcnB is a small ( $\sim 3 \mathrm{kDa}$ ), 
hydrophobic, positively charged peptide with an antimicrobial spectrum limited to Lactococcus species (Venema et al., 1997). Its mode of action relies on binding to components of the mannose phosphotransferase system (man-PTS) of susceptible cells, causing leakage of cellular components across the membrane (Diep et al., 2007).

It has been observed previously that the activity of $\operatorname{LcnB}$ is affected by media peptide concentration. Peptide-rich media were proven to promote activity, while peptide-poor media minimize LcnB activity. This was reported in experiments with both chemically defined media (Gajic et al., 1999; Miladinov et al., 2001), and GM17 media (Venema et al., 1997)

In this research we focus on the interaction between proteinase PrtP and bacteriocin LcnB in BGMN1-501, given that, so far, no information exists on this matter. We explored the promoter activity of $l c n B$ during growth in different casitone concentrations, and showed that expression of $\mathrm{LcnB}$ is silenced in a peptide rich environment, which is contrary to the prevailing belief. Moreover, we offer evidence of the digestion of LcnB by proteinase PrtP, which drastically, but not completely, reduces its activity. Bringing these facts together, we propose a model of $l c n B$ regulation which sheds new light on the complex interaction between these proteins and their environment.

\section{MATERIALS AND METHODS BACTERIAL STRAINS AND PLASMIDS}

The bacterial strains and plasmids used in this study are listed in Tables 1 and 2. Lactococcal strains were grown in M17 medium (Merck) supplemented with D-glucose $(0.5 \% \mathrm{w} / \mathrm{v} ; \mathrm{GM} 17)$ at $30^{\circ} \mathrm{C}$, unless otherwise noted. Escherichia coli DH5 $\alpha$ and EC101, used for cloning and propagation of constructs, were grown in Lauria-Bertani (LB) broth (Miller, 1972) aerobically at $37^{\circ} \mathrm{C}$. Agar plates were made by adding $1.5 \%$ (w/v) agar (Torlak Belgrade, Serbia) to the liquid media. Transformants of lactococci were selected on GM17 plates containing $10 \mu \mathrm{g} / \mathrm{ml}$ of erythromycin (SigmaAldrich Chemie GmbH, Deisenhofen, Germany) or $7.5 \mu \mathrm{g} / \mathrm{ml}$ of chloramphenicol in the final concentration. E. coli transformants were selected on LB plates containing $300 \mu \mathrm{g} / \mathrm{ml}$ of erythromycin, $35 \mu \mathrm{g} / \mathrm{ml}$ of chloramphenicol, or $100 \mu \mathrm{g} / \mathrm{ml}$ of ampicillin, depending on the plasmids used. When necessary, 5-bromo-4-chloro-3indolyl-D-galactoside (X-gal; Fermentas, Vilnius, Lithuania) was added to LB or GM17 medium plates at a final concentration of $50 \mu \mathrm{g} / \mathrm{ml}$ for blue/white screening of colonies carrying vectors with clones.

\section{BACTERIOCIN ACTIVITY ASSAY}

The bacteriocin activity of L. lactis subsp. lactis BGMN1-501, recombinant strains and mutants was evaluated by an agar-well diffusion test (Lozo et al., 2004). Tested strains were grown in GM17 medium with different concentrations of casitone $(0.5 \%$, $1 \%, 2 \%, 4 \%, 6 \%$, and 8\%; Difco Laboratories, Becton Dickinson and Company, Franklin Lakes, NJ, USA). The cell-free supernatants of tested strains were obtained by centrifugation (13000 rpm for $10 \mathrm{~min}$ ) of 16-h overnight culture and subsequent filtration through a $0.45 \mu \mathrm{m}$ filter to obtain LcnB extracts. L. lactis subsp. lactis BGMN1-596 was used as an indicator strain. Clear zones of inhibition around the wells were used as positive signals for bacteriocin production.

\section{PROTEINASE ACTIVITY ASSAY}

For proteinase activity analysis of the obtained mutants, the method described by Kojic et al. (1991) was used. Cells were induced by growing on milk-citrate-agar (MCA) plates [containing $4.4 \%$ reconstituted milk, $0.8 \%$ Na-citrate, $0.1 \%$ yeast

Table 1 | Bacterial strains used in this study.

\begin{tabular}{|c|c|c|}
\hline Strains & Relevant characteristic(s) & $\begin{array}{l}\text { Source or } \\
\text { reference }\end{array}$ \\
\hline \multicolumn{3}{|l|}{ Lactococcus lactis subsp. lactis } \\
\hline BGMN1-501 & Derivate of BGMN1-5 with pMN80 plasmid, $\mathrm{LcnB}^{+}, \mathrm{PrtP}^{+}, \mathrm{LcnB}^{r}$ & Kojic et al. (2006) \\
\hline BGMN1-596 & Plasmid free derivate of BGMN1-5, $\mathrm{LcnB}^{-}, \mathrm{PrtP}^{-}, \mathrm{LcnB}^{\mathrm{s}}$ & Kojic et al. (2006) \\
\hline BGMN1-501/pG+host9prtP & $\operatorname{PrtP}^{-}, \mathrm{LcnB}^{+}, \mathrm{LcnB}^{r}$ & This work \\
\hline \multicolumn{3}{|l|}{ L. lactis subsp. cremoris } \\
\hline NCDO712 & $\mathrm{PrtP}^{+}, \mathrm{Lac}^{+}$ & Gasson (1983) \\
\hline MG7284 & Plasmid free derivative of $\mathrm{NCDO} 12, \mathrm{PrtP}^{-}, \mathrm{Lac}^{-}$ & Gasson (1983) \\
\hline MG7284/pNZ8150lacZ1PIcnB & & This work \\
\hline EC101 & JM101 containing repA gene of pWV01 in chromosome & Law et al. (1995) \\
\hline DH5 $\alpha / p G e m-T-e a s y l c n B$ & & This work \\
\hline EC101/pG+host9prtP & & This work \\
\hline EC101/pG+host9lenB & & This work \\
\hline
\end{tabular}


Table 2 | Plasmids used in this study.

\begin{tabular}{|c|c|c|}
\hline Plasmids & Relevant characteristic(s) & Source or reference \\
\hline $\mathrm{pG}^{+}$host9 & $\mathrm{Em}^{\mathrm{r}}$, thermosensitive vector & Maguin et al. (1996) \\
\hline $\mathrm{pG}^{+}$host9lenB & $\mathrm{pG}^{+}$host9 carrying whole $\operatorname{Icn} B$ gene & This work \\
\hline Q6 & M13mp10 with $1.1 \mathrm{kbp}$ carrying fragment of prtP gene & Kojic et al. (1991) \\
\hline pNZ8150 & Scal site used for translational fusions, standard vector; $\mathrm{Cm}^{r}$ & Mierau and Kleerebezem (2005) \\
\hline pNZ8150lacZ1 & & This work \\
\hline pNZ8150lacZ1PlcnB & & This work \\
\hline pGem-T-Easy & $3015 \mathrm{bp} ; \mathrm{Amp}^{\mathrm{r}}$; PCR cloning vector & Promega \\
\hline
\end{tabular}

extract, $0.5 \%$ glucose, and $1.5 \%$ agar $(\mathrm{w} / \mathrm{v})]$ for $48 \mathrm{~h}$ at $30^{\circ} \mathrm{C}$ prior to collection. Collected fresh cells were resuspended in $0.1 \mathrm{~mol} / \mathrm{L}$ sodium phosphate buffer $(\mathrm{pH} 7) . \beta$ casein (Sigma-Aldrich) was dissolved in the same buffer at $5 \mathrm{mg} / \mathrm{ml}$ final concentration. The cell suspension containing $10^{9}$ cells per $\mathrm{mL}$ was mixed with $\beta$-casein solution at a $1: 1$ $(\mathrm{v} / \mathrm{v})$ ratio. After incubation for $4 \mathrm{~h}$ at $30^{\circ} \mathrm{C}$, the cells were pelleted by centrifugation $(13000 \times g, 10 \mathrm{~min})$, the clear supernatant fluid was taken off and samples were prepared for SDS-PAGE.

For in vitro testing of the proteinase's effect on bacteriocin activity, cell-free proteinase extract was prepared. Cells were grown on MCA plates, collected and re-suspended in $0.1 \mathrm{~mol} / \mathrm{L}$ sodium phosphate buffer ( $\mathrm{pH} 7)$, incubated at room temperature for $30 \mathrm{~min}$, pelleted by centrifugation and supernatants were collected prior to reaction.

Samples for SDS-PAGE were mixed with sample loading buffer (0.125 mol/L TrisHCl, pH 6.8, $0.01 \mathrm{mmol} / \mathrm{L}$ EDTA, 4\% SDS, 25\% glycerol, 5\% 2-mercaptoethanol, and $0.07 \%$ bromophenol blue) at a 1:1 ratio by volume. Before loading, samples were heated at $100^{\circ} \mathrm{C}$ for $5 \mathrm{~min}$.

\section{INTEGRATION OF PLASMID pG ${ }^{+}$HOST9 INTO pMN80}

The plasmid $\mathrm{pG}^{+}$host 9 , a thermosensitive erythromycin-resistant derivate of the plasmid pWVO1 (Maguin et al., 1992), was used to construct the integrative vector for disrupting prtP and $\operatorname{lcn} B$ genes, located on plasmid pMN80 of L. lactis BGMN1-501. A $1.1 \mathrm{kbp}$ fragment containing the DNA region coding for the active site of PrtP proteinase of L. lactis subsp. cremoris Wg2, necessary for inactivation based on homologous recombination, was obtained from M13-Q6 vector (Kojic et al., 1991) using EcoRI and HindIII restriction enzymes and then was cloned into $\mathrm{pG}^{+}$host9 to yield $\mathrm{pG}^{+}$host9prtP. A PCR fragment of $578 \mathrm{bp}$ containing gene lcnB was cloned into commercial pGem-T-easy vector (Promega, Madison, WIS, USA) to yield pGem-T-easylcnB, and subsequently cloned into $\mathrm{pG}^{+}$host9 vector digested with EcoRI, resulting in the construct $\mathrm{pG}^{+}$host9lcnB. Constructs $\mathrm{pG}^{+}$host9prtP and
$\mathrm{pG}^{+}$host9lcnB were used for transformation of BGMN1-501. Transformants obtained at $28^{\circ} \mathrm{C}$ were streaked onto fresh GM17 agar plates containing erythromycin $(10 \mu \mathrm{g} / \mathrm{ml})$ and incubated at $37^{\circ} \mathrm{C}$ for $48 \mathrm{~h}$ to enable integration.

\section{MOLECULAR TECHNIQUES}

Pulsed-field gel electrophoresis (PFGE) was used for clonal confirmation, as described by Kojic etal. (2005). Total DNA from lactococci was isolated by the modified methods described by Hopwood et al. (1985). The method used for mini-prep isolation of plasmid DNA from lactococci was described by O'sullivan and Klaenhammer (1993). For isolation of plasmid DNA from E. coli, a QIAprep Spin Miniprep Kit was used according to the manufacturer's recommendations (Qiagen, Hilden, Germany). All digestions with restriction enzymes were conducted according to the supplier's instructions (Fermentas, Lithuania). T4 DNA ligase (Agilent Technologies, Santa Clara, CA, USA) was used for DNA ligation, according to the manufacturer's recommendation. Plasmid constructs were introduced into lactococci by electroporation using an Eporator (Eppendorf, Hamburg, Germany) using the methodology described by Holo and Nes (1989). The sets of specific primers used in this study are listed in Table 3. KapaTaq DNA polymerase (KapaBiosystem, Inc., Boston, MA, USA) was used to amplify DNA fragments by PCR using a GeneAmp PCR system 2700 thermal cycler (Applied Biosystems, Foster City, CA, USA). DNA fragments were purified from agarose gel using a QIAquick Gel extraction kit as described by the manufacturer (Qiagen). PCR products were purified with a QiaQuick PCR purification kit (Qiagen) according to the protocol of the supplier. Obtained and purified PCR products were sequenced by the Macrogen Sequencing Service (Macrogen, Netherlands) and analyzed by using the BLAST algorithm. Commercial p-Gem-T-Easy (Promega) vector was used for cloning PCR products.

\section{PLASMID CONSTRUCTION}

A transcription fusion vector for lactococci (named pNZ8150lacZ1) was constructed as follows. The lac $Z 1$ gene without promoter was 
Table 3 | Sequence of specific primers used in this study.

\begin{tabular}{llll}
\hline Primer name & Sequence of primer & Template & Source or reference \\
\hline LactABM-F & $5^{\prime}$-gaagaggcaatcagtagag- 3' & pMN80 plasmid DNA & Alegría etal. (2010) \\
LactB-R & $5^{\prime}$-ccaggatttctttgatttacttc- 3' & pMN80 plasmid DNA & Alegría etal. (2010) \\
PlcnB-FW & $5^{\prime}$-ctgcagagttattaacatttgttaacg-3' & pMN80 plasmid DNA & This work \\
PlcnB-REV & $5^{\prime}$-gagctcgattttcataataatctcc- 3' & pMN80 plasmid DNA & This work \\
\hline
\end{tabular}

removed from $\mathrm{pUT} / \mathrm{Km}$ vector using EcoRI-HindIII restriction enzymes and cloned first into pBlueScript vector digested with the same enzymes, yielding the construct pBSlacZ1. From pBSlacZ1, the lacZ1 gene was re-cloned into pNZ8150 vector (Mierau and Kleerebezem, 2005) using PstI-HindIII restriction enzymes, resulting in construct pNZ8150lacZ1. This vector contained restriction enzyme sites for cloning promoter fragments upstream of the lacZ1 gene (ScaI, PstI, EcoRI, SmaI, and BamHI). The orientation and position of the lacZ1 gene in pNZ8150lacZ1 was confirmed by sequencing in both orientations. The $\ln B$ promoter region $\left(\mathrm{P}_{l c n B}\right)$ was amplified using specific primers, PlcnB-FW and PlcnB-REV (Table 3), and cloned into pGEM-T-easy, yielding pGEM-TeasyPlcnB. The promoter region was removed from pGEM-TeasyPlcnB by PstI and EcoRI restriction enzymes and cloned into pNZ8150lacZ1 vector digested with the same enzymes, to yield construct pNZ8150lacZ1PlcnB. The activity of $\operatorname{lcn} B$ promoter in pNZ8150lacZ1PlcnB was confirmed by a $\beta$ galactosidase activity assay of L. lactis subsp. cremoris MG7284 carrying pNZ8150lacZ1PlcnB ( $\mathrm{P}_{l c n B}$ transcription fusion) and pNZ8150lacZ1 (negative control).

\section{B-GALACTOSIDASE ACTIVITY ASSAY}

The activity of $\beta$-galactosidase was determined by assaying the degradation of ortho-nitrophenyl- $\beta$-D-galactopyranoside (ONPG; Sigma-Aldrich) at $30^{\circ} \mathrm{C}$ using a modification of the method described by Miller (1972). Lactococcal cells from the logarithmic phase were harvested by centrifugation and resuspended in $500 \mu \mathrm{l}$ of PP buffer containing $4 \mathrm{mg}$ of lysozyme per milliliter. Degradation of the cell wall was conducted for $30 \mathrm{~min}$ at $37^{\circ} \mathrm{C}$. After that, cells were harvested by centrifugation $(5 \mathrm{~min}$ at $5000 \times g)$. Cell pellets were resuspended in $500 \mu \mathrm{l}$ of Z-buffer and the protocol was continued as described previously (Miller, 1972).

\section{IN VITRO TESTING OF EFFECT OF PROTEINASE EXTRACT ON LcnB ACTIVITY}

LcnB extracts from both BGMN1-501 and BGMN1-501/pG ${ }^{+}$host 9prtP were incubated with proteinase extract from BGMN1$501 / \mathrm{pG}^{+}$host9lcnB $\left(\mathrm{LcnB}^{-}, \mathrm{PrtP}^{+}\right)$. The extracts were mixed at a $1: 1$ ratio, and incubated at $30^{\circ} \mathrm{C}$ for $120 \mathrm{~min}$. In parallel, LcnB extracts from both strains were incubated with $\mathrm{NaPi}$ buffer $(0.1 \mathrm{~mol} / \mathrm{L}, \mathrm{pH} 7)$ at a $1: 1$ ratio at $37^{\circ} \mathrm{C}$ for $120 \mathrm{~min}$, as a control. Proteinase PrtP's effect on LcnB activity was tested in the same conditions by using proteinase extract isolated from L. lactis subsp. cremoris NCDO712.

\section{MEASUREMENT OF LACTOCOCCIN B GROWTH INHIBITION ZONES' DIAMETERS}

Diameters of growth inhibition zones formed in bacteriocin activity assay from extracts of both BGMN1-501 and BGMN1-501/ $\mathrm{pG}^{+}$host9prtP were measured using AutoCAD 12 (Autodesk, San Rafael, CA, USA).

\section{RESULTS \\ CONSTRUCTION OF MUTANT STRAINS}

Integration of the appropriate plasmid constructs ( $\mathrm{pG}^{+}$host9prtP and $\mathrm{pG}^{+}$host $91 \mathrm{cnB}$ ) into corresponding prtP and $l \mathrm{cnB}$ genes on plasmid pMN80, after growing L. lactis subsp. lactis BGMN1-501 transformants at $37^{\circ} \mathrm{C}$ for $48 \mathrm{~h}$, was confirmed by their PrtP $\mathrm{P}^{-}$ and $\mathrm{LcnB}^{-}$phenotype, as well as PFGE analysis. As expected, the mutants with integrated $\mathrm{pG}^{+}$host9prtP construct in the prtP gene lost the ability to degrade $\beta$-casein ( $\mathrm{PrtP}^{-}$mutant; Figure 1) and mutants with $\mathrm{pG}^{+}$host9lcnB construct integrated into $\operatorname{lcnB}$ showed $\mathrm{LcnB}^{-}$phenotype (Figure 2). PFGE (SmaI macrorestriction) analysis of BGMN1-501, transformants with free constructs ( $\mathrm{pG}^{+}$host9prtP and $\mathrm{pG}^{+}$host9lcnB) and mutants confirmed the integration of constructs into plasmid pMN80 at different positions (it is possible to conclude that the distance between prtP and $l c n B$ on plasmid pMN80 is at least $35 \mathrm{~kb}$; Figure 3). Construction of an $\mathrm{LcnB}^{-}$mutant was undertaken in order to eliminate the possible presence of $\mathrm{LcnB}$ molecules in proteinase extracts used for in vitro LcnB activity analyses.

\section{BACTERIOCIN ACTIVITY IS MEDIUM DEPENDENT IN BGMN1-501, BUT NOT IN BGMN1-501/pG ${ }^{+}$HOST9prtP (ITS PrtP- MUTANT)}

The bacteriocin activity of BGMN1-501 and its $\mathrm{PrtP}^{-}$mutant was analyzed after $16 \mathrm{~h}$ of growth in GM17 with different concentrations of casitone $(0 \% \mathrm{w} / \mathrm{v}, 0.5 \% \mathrm{w} / \mathrm{v}, 1 \% \mathrm{w} / \mathrm{v}, 2 \% \mathrm{w} / \mathrm{v}$, $4 \% \mathrm{w} / \mathrm{v}, 6 \% \mathrm{w} / \mathrm{v}$, and $8 \% \mathrm{w} / \mathrm{v})$, assayed by the agar well diffusion test on indicator strain BGMN1-596. Casitone is a pancreatic digest of casein mainly consisting of small peptides and amino acids in a ratio of about 4:1 (Marugg et al., 1995). Increasing casitone concentration resulted in higher bacteriocin activity of BGMN1-501 (Figure 4). On the contrary, the bacteriocin activity of $\mathrm{PrtP}^{-}$mutant remained unaffected by changes in casitone concentration. It is noteworthy that the zones of inhibition for the mutant were larger than the largest zone BGMN1-501 produced.

\section{IcnB PROMOTER IS UNDER MEDIUM DEPENDENT REGULATION}

The transcription fusion vector described here, pNZ8150lacZ1, is the first such vector for expression analysis constructed for 


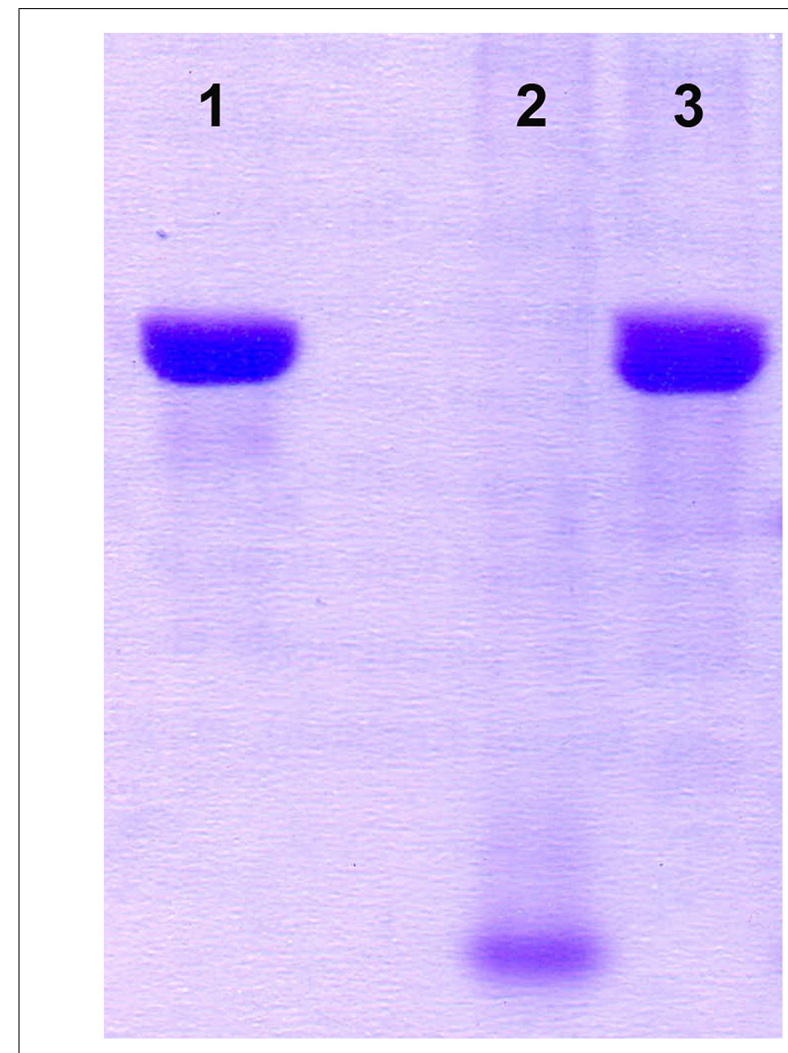

FIGURE 1 | Analysis of proteinase inactivity of BGMN1-501/pG ${ }^{+}$ host9prtP integrant. (1) $\beta$-casein, (2) BGMN1-501, (3) prtP integrant.

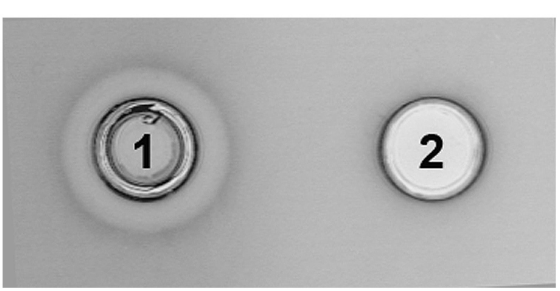

FIGURE 2 | Analysis of bacteriocin inactivity of BGMN1-501/pG+ host9lcnB integrant. (1) BGMN1-501, (2) IcnB integrant.

lactococci. It has several applicable advantages: favorable selection, multiple restriction enzyme sites, high copy-number, and a common reporter gene. It proved to be reliable, easy to manipulate, and showed highly reproducible results.

The $l c n B$ promoter region was cloned upstream of promoter-less lacZ1 gene in pNZ8150lacZ1 vector, to yield pNZ8150lacZ1PlcnB. The construct was introduced into the proteinase-deficient $L$. lactis subsp. cremoris MG7284. The transformant MG7284/pNZ8150lacZ1PlcnB was streaked onto GM17 Petri dishes containing $7.5 \mu \mathrm{g} / \mathrm{ml}$ of chloramphenicol and $50 \mu \mathrm{g} / \mathrm{ml}$ of X-gal, turning apparently blue (data not shown). The $\beta$-galactosidase production of transformant MG7284/pNZ8150lacZ1PlcnB was analyzed during growth in GM17 media with different concentrations of casitone $(0 \%, 0.5 \%$, $1 \%, 2 \%, 4 \%, 6 \%$, and $8 \%$ ). The promoter showed a significant

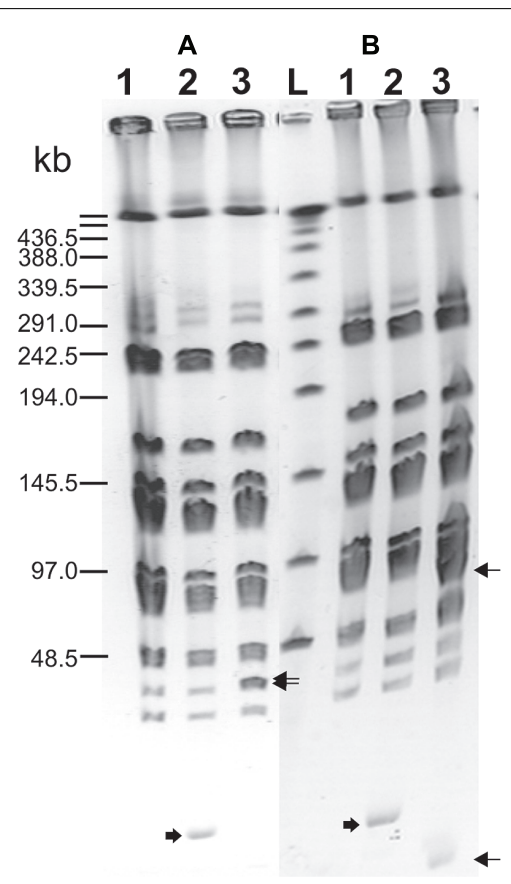

FIGURE 3 | Pulsed-field gel electrophoresis (Smal macroresriction pattern) of PrtP- (A) and $\mathrm{LcnB}^{-}$(B) mutants of BGMN1-501. (1) BGMN1-501; (2) BGMN1-501 carrying adequate free $\mathrm{pG}^{+}$host with fragment for homologous recombination (growth at $28^{\circ} \mathrm{C}$ ); (3) mutants of BGMN1-501; $L$, phage $\lambda$ DNA concatemers. Wide arrows indicate free $\mathrm{pG}^{+}$host with a fragment for homologous recombination, sharp arrows indicate the appearance of new Smal fragments in generated mutants after insertion of $\mathrm{pG}^{+}$host vectors ( $\mathrm{pG}^{+}$host introduces additional Smal site).

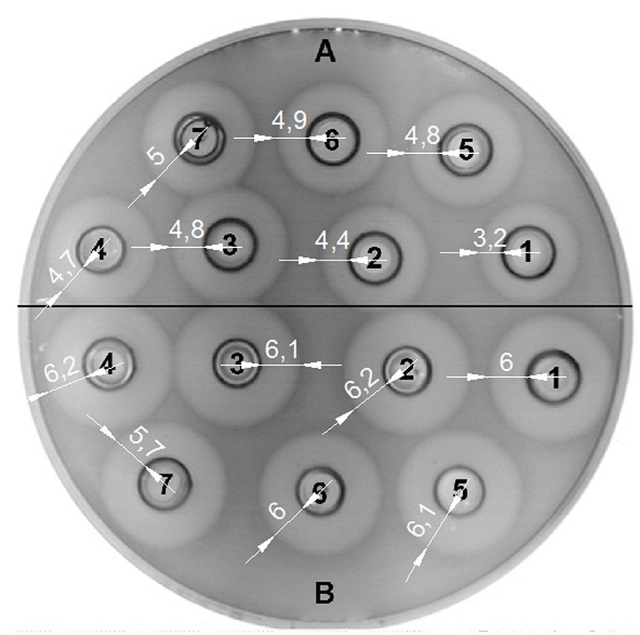

FIGURE 4 | Activity of LcnB synthesized by BGMN1-501 and BGMN1-501/pG ${ }^{+}$host9prtP (PrtP- mutant) after growth in GM17 media with different concentration of casitone. (A) LcnB activity of BGMN1-501 after growth in GM17 with (1) 0\%; (2) 0.5\%; (3) $1 \%$; (4) $2 \%$; (5) $4 \%$; (6) $6 \%$; (7) $8 \%$; of casitone. The zones of growth inhibition enlarge as the concentration of casitone grows; (B) LcnB activity of

BGMN1-501/pG+host9prtP (PrtP- mutant) after growth in GM17 with (1) $0 \%$; (2) $0.5 \%$; (3) $1 \%$; (4) $2 \%$; (5) $4 \%$; (6) $6 \%$; (7) $8 \%$; of casitone. Note that the zones of growth inhibition are not dependent on casitone concentration in the media. 


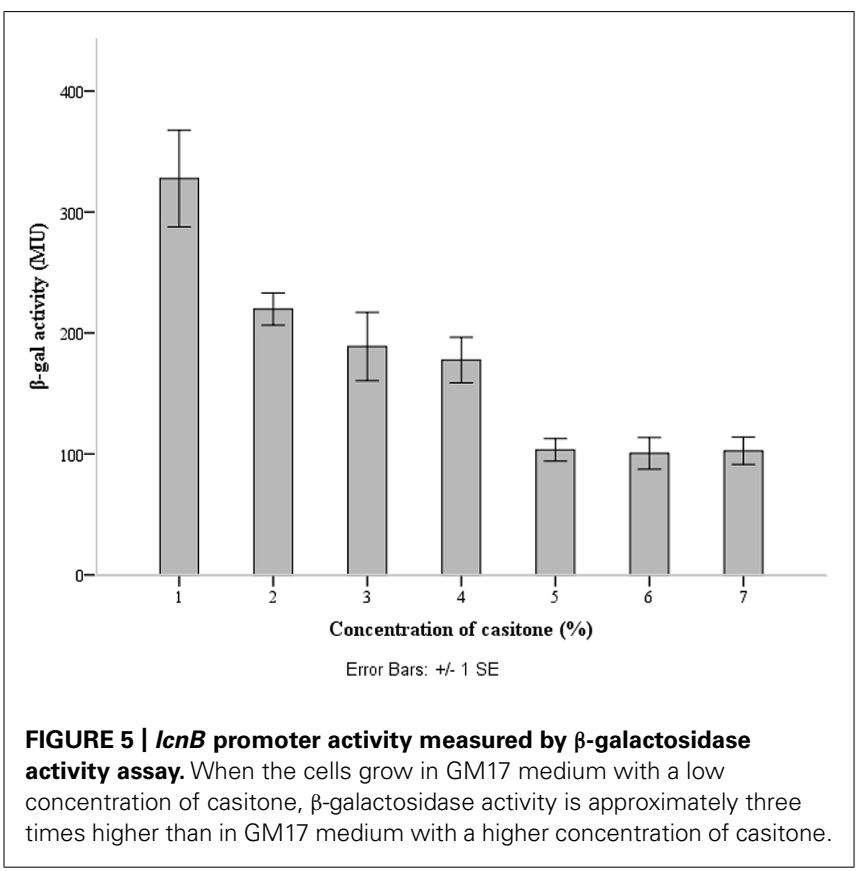

decline in activity in media with higher casitone concentration, but only to a certain point. After $4 \%$, the rise of casitone concentration in the medium had no silencing effect on the $l c n B$ promoter (Figure 5).

\section{ACTIVITY OF LACTOCOCCIN B IS REDUCED BY PrtP}

We examined whether the activity of $\operatorname{LcnB}$ can be modified by PrtP proteinase in vitro. LcnB extracts, both from BGMN1-501 and its $\mathrm{PrtP}^{-}$mutant, were mixed in parallel with NaPi buffer and proteinase extract and incubated for $120 \mathrm{~min}$ at $30^{\circ} \mathrm{C}$. After incubation with proteinase, the LcnB activity of BGMN1-501 was not altered (Figure 6, wells 1 and 2). In contrast, the bacteriocin activity of the PrtP ${ }^{-}$mutant decreased drastically (Figure 6, wells 3 and 4). The decrease in activity was monitored at several time points

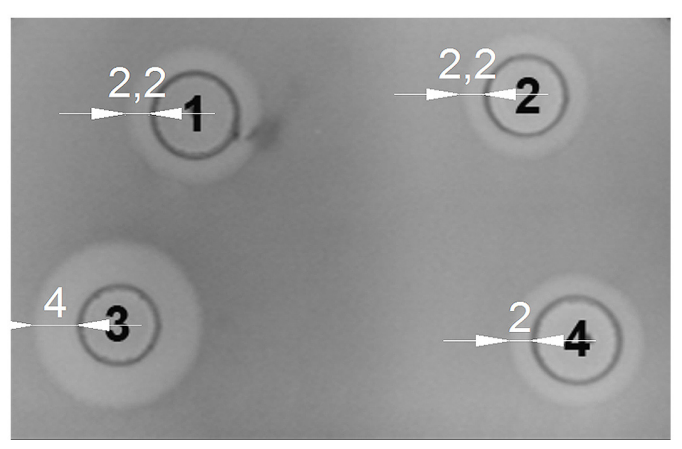

FIGURE 6 | LcnB activity of BGMN1-501 and its PrtP- mutant before and after incubation with PrtP proteinase extract of BGMN1-501/pG ${ }^{+}$host9lenB (LenB ${ }^{-}$mutant). (1) LcnB of BGMN1-501 with NaPi; (2) LcnB of BGMN1-501 with PrtP of BGMN1-501/pG ${ }^{+}$host9lenB; (3) LcnB of PrtP ${ }^{-}$mutant with NaPi; (4) LcnB of BGMN1-501/pG ${ }^{+}$host9prtP with PrtP proteinase of BGMN1-501/pG ${ }^{+}$host9lcnB. Note that the zone of growth inhibition is rendered to that of the original strain. and it was continuous until $1 \mathrm{~h}$ of incubation (data not shown). After $1 \mathrm{~h}$, zones of growth inhibition were constant regardless of incubation time with proteinase extract, indicating that in $1 \mathrm{~h}$ all of the LcnB was processed by proteinase extract. The same result was observed when proteinase extract from L. lactis subsp. cremoris NCDO712 (a producer of the same type of PrtP proteinase as BGMN1-501) was used (data not shown).

\section{DISCUSSION}

The production of bacteriocin LcnB, it's genetics, spectrum of activity, mode of action, and medium dependent activity have been studied in detail (van Belkum et al., 1991; Venema et al., 1993, 1996; Gajic et al., 1999; Diep et al., 2007). In addition, it was determined that $\mathrm{LcnB}$ is sensitive to degradation by several proteases (pepsin, trypsin, chymotrypsin, pronase $\mathrm{E}$, proteinase $\mathrm{K}$ ) and that high concentrations of peptides in growth media induce its activity. Nevertheless, neither regulation of $l c n B$ gene expression, nor the active/binding domain was described.

We analyzed the activity of the $\operatorname{lcn} B$ gene promoter by cloning it in pNZ8150lacZ1 transcription fusion vector, which we developed for expression analyses in lactococci. For this, we chose pNZ8150 cloning and expression vector with broad range replication and a chloramphenicol resistance marker because it could be cotransformed with other cloning vectors for lactococci, e.g., pAZIL (Kojic et al., 2011). This also enables analysis of the relationship between the promoter region and certain cloned gene(s) in homologous and heterologous hosts. In addition we established and standardized a simple protocol for detection and measurement of $\beta$-galactosidase activity in lactococci. Using this system we obtained very reproducible results and high values of $\beta$-galactosidase activity in lactococci, in contrast to other authors (Roces etal., 2012). This enabled us to analyze the medium-dependent activity of $\operatorname{lcn} B$ gene promoter. Through the activity of a common reporter gene (lac $Z$ ) we were able to quantify promoter activity in different growth media. Surprisingly, it turned out that promoter activity was continuously attenuated, inversely to the increase of casitone concentration. This was completely contrary to the assumptions of previous researchers (i.e., Venema etal., 1997) and from our experiments, which clearly indicated an increase of bacteriocin activity in peptide-rich media (Figure 4). It seems that with higher peptide concentration in the growth medium, less of the bacteriocin gene is transcribed, but somehow its activity becomes higher. We assumed that the observed bacteriocin activity indicated the activity of bacteriocin molecules themselves, rather than their number. This activity is apparently changeable in vivo, and we suppose that either some kind of enhanced translation or post-translational modification, which is related to different peptide concentrations in media, occurs to bacteriocin. The effect of this modification is so strong that it not only compensates for the fall in bacteriocin expression, but overcomes this effect, making even larger zones of growth inhibition of indicator strains.

Since it has long been known that PrtP expression is highly dependent on casitone concentration in media, the possible impact of proteinase on bacteriocin activity was investigated. prtP was knocked out from L. lactis BGMN1-501, and mutants were 
screened for bacteriocin activity in media with different casitone concentrations. Two results were of great importance: (i) zones of growth inhibition were greatly enlarged, suggesting that the lack of PrtP stimulates LcnB activity and (ii) interdependence of LcnB activity and casitone concentration was lost. Zones of growth inhibition were approximately the same size, although cultures were grown in different media. We reasoned that $\mathrm{LcnB}$ may be a substrate for PrtP proteinase, given its proteinaceous nature. Indeed, in vitro mixing of $\mathrm{LcnB}$ and PrtP extracts indicated that proteinase impairs the function of $\mathrm{LcnB}$. After treatment with PrtP, the activity of the mutant's LcnB was greatly reduced and corresponded perfectly to the activity of the original strain's LcnB. Moreover, the activity of LcnB extracted from the original strain was not changed with proteinase treatment. We assume that all molecules of $\mathrm{LcnB}$ in the original strain had already been digested with intrinsic proteinase, which left no target bonds for additionally added PrtP to cleave.

Lasta et al. (2008) showed that the first six amino acids from the $\mathrm{N}$ terminus are crucial for $\mathrm{LcnB}$ bactericidal activity, which is why we suppose that cleavage occurs at this location. This assumption is corroborated by the findings of Juillard et al. (1995) who showed that PrtP cleaves, among others, the peptide bond between leucine and glutamine in $\beta$-casein. These are the second and third amino acids on the $\mathrm{N}$ terminus of bacteriocin $\mathrm{LcnB}$.

We propose a model of $l c n B$ expression regulation in which the absence of PrtP in the environment leads to the presence of undigested and hence fully active molecules of LcnB in the media. This happens in a peptide rich environment where growth conditions are favorable for producers, but also for numerous competing bacteria. Given that these molecules possess excessively strong activity, bacteria reduce their production by silencing $\ln B$ transcription several-fold. On the other hand, when bacteria enter a peptide-poor environment, PrtP is highly expressed on the cell surface, as a tool for obtaining small peptides from proteins. Consequent digestion of present LcnB molecules renders them less active but leads to initial elevation of small peptides or free amino acids in the environment. As a consequence of lower LcnB activity, $\operatorname{lcn} B$ transcription magnifies.

It should be mentioned that in L. lactis BGMN1-501, genes $l c n B$ and prtP are located on the same genetic element. It is tempting to assume that these genes co-evolved, at least in some lactococci. On the other hand, there are a number of strains harboring only one of these genes, as well as those which harbor them on separate plasmids (Miladinov et al., 2001). Hence, we must not exclude the possibility of a non-functional adverse effect of proteinase on bacteriocin and that there is another explanation of bacteriocin activity enhancement parallel to attenuation of its gene expression, but we consider this not accidental. It should be noted that PrtP proteinase also digests itself in a process of autocatalytic release from cells into the medium (Laan and Konings, 1989; Bruinenberg et al., 1994; Flambard and Juillard, 2000). It is also known that bacteria use proteinases as a defense mechanism against attacks by bacteriocin-producing bacteria (Nawrocki et al., 2014), but it is still debatable why bacteria would impair their own bacteriocin. The fact that it does not destroy it completely implies some regulation-based explanation. It is certain that as a consequence of this action a pool of small peptides rapidly generates in the close vicinity of nitrogen-depleted bacterial cells. Perhaps this "self-digestion" has a physiological role in some sort of first aid for bacteria which find themselves in a peptide-poor environment, especially if we take into account that antimicrobial activity for inhibiting the growth of neighboring bacteria is retained.

Defining the exact peptide bond or bonds that are cleaved in LcnB by the proteinase will lead to a better understanding of the structure-function relationships in the bacteriocin and help define its receptor binding domain as well as its mode of action.

In conclusion we wish to point out that our results are of both fundamental and applicable significance. They provide new insight into bacteriocin activity, opening a new field of transcriptional and translational regulation of bacteriocin expression. Also, it is reasonable to consider that similar regulation may exist in bacteriocins that are already used in food preservation or in ones that might be used in the future. Since it is not unusual for bacteriocin and proteinase producers to be applied in food production, our work indicates that their interaction should be taken into account when planning the final concentration of desired active molecules.

\section{AUTHOR CONTRIBUTIONS}

GV, NM, and MM contributed to acquisition and analysis of data; BJ, IS, ZR, and DF contributed to design of the work, analysis, and interpretation of the data; GV, NM, and BJ drafted the manuscript; MK contributed to the conception of the work and did final approval of the version to be published.

\section{ACKNOWLEDGMENTS}

This work was supported by the Ministry of Education, Science and Technological Development, Republic of Serbia (Grants No. 173019 and 173026).

\section{REFERENCES}

Alegría, A., Delgado, S., Roces, C., López, B., and Mayo, B. (2010). Bacteriocins produced by wild Lactococcus lactis strains isolated from traditional, starter-free cheeses made of raw milk. Int. J. Food Microbiol. 143, 61-66. doi: 10.1016/j.ijfoodmicro.2010.07.029

Bruinenberg, P. G., de Vos, W. M., and Siezen, R. J. (1994). Prevention of C-terminal autoprocessing of Lactococcus lactis SK11 cell-envelope proteinase by engineering of an essential surface loop. Biochem. J. 302, 957-963.

Calasso, M., Di Cagno, R., De Angelis, M., Campanella, D., Minervini, F., and Gobbetti, M. (2013). Effects of the peptide pheromone plantaricin A and cocultivation with Lactobacillus sanfranciscensis DPPMA174 on the exoproteome and the adhesion capacity of Lactobacillus plantarum DC400. Appl. Environ. Microbiol. 79, 2657-2669. doi: 10.1128/AEM.03625-12

Cotter, P. D. (2014). An "Upp"-turn in bacteriocin receptor identification. Mol. Microbiol. 92, 1159-1163. doi: 10.1111/mmi.12645

de Lorenzo, V., Herrero, M., Jakubzik, U., and Timmis, K. N. (1990). Mini-Tn5 transposon derivatives for insertion mutagenesis, promoter probing, and chromosomal insertion of cloned DNA in Gram-negative eubacteria. J. Bacteriol. 172, 6568-6572.

Diep, D. B., Skaugen, M., Salehian, Z., Holo, H., and Nes, I. F. (2007). Common mechanisms of target cell recognition and immunity for class II bacteriocins. Proc. Natl. Acad. Sci. U.S.A. 104, 2384-2389. doi: 10.1073/pnas.0608775104

Flambard, B., and Juillard, V. (2000). The autoproteolysis of Lactococcus lactis lactocepin III affects its specificity towards $\beta$-casein. Appl. Environ. Microbiol. 66, 5134-5140. doi: 10.1128/AEM.66.12.5134-5140.2000

Gajic, O., Kojic, M., Banina, A., and Topisirovic, L. (1999). Characterization of natural isolate Lactococcus lactis subsp. lactis BGMN1-5, a strain producing two 
bacteriocins, cell wall-associated proteinase and showing clumping phenotype. Arch. Biol. Sci. 59, 69-78.

Gasson, M. J. (1983). Plasmid complements of Streptococcus lactis NCDO 712 and other lactic streptococci after protoplast-induced curing. J. Bacteriol. 154, 1-9.

Hanahan, D. (1983). Studies on transformation of Escherichia coli with plasmids. J. Mol. Biol. 166, 557-580. doi: 10.1016/S0022-2836(83)80284-8

Hayes, M., Stanton, C., Fitzgerald, G., and Ross, R. P. (2007). Putting microbes to work: dairy fermentation, cell factories and bioactive peptides. Part II: bioactive peptide functions. Biotechnol. J. 2, 435-449. doi: 10.1002/biot.200700045

Holo, H., and Nes, I. F. (1989). High-frequency transformation, by electroporation, of Lactococcus lactis subsp. cremoris grown with glycine in osmotically stabilized media. Appl. Environ. Microbiol. 55, 3119-3123.

Hopwood, D. A., Bibb, M. J., Chater, K. F., Kieser, T., Bruton, C. J., Kieser, H. M., et al. (1985). Genetic Manipulation of Streptomyces - A Laboratory Manual. Norwich: The John Innes Foundation.

Juillard, V., Laan, H., Kunji, E. R., Jeronimus-Stratingh, C. M., Bruins, A. P., and Konings, W. N. (1995). The extracellular PI-type proteinase of Lactococcus lac tis hydrolyzes beta-casein into more than one hundred different oligopeptides. J. Bacteriol. 177, 3472-3478.

Kojic, M., Fira, D., Banina, A., and Topisirovic, L. (1991). Characterization of the cell wall-bound proteinase of Lactobacillus casei HN14. Appl. Environ. Microbiol. 57, 1753-1757.

Kojic, M., Jovcic, B., Strahinic, I., Begovic, J., Lozo, J., Veljovic, K., et al. (2011). Cloning and expression of a novel lactococcal aggregation factor from Lactococcus lactis subsp. lactis BGKP1. BMC Microbiol. 11:265. doi: 10.1186/1471-2180-11265

Kojic, M., Strahinic, I., Fira, D., Jovcic, B., and Topisirovic, L. (2006). Plasmid content and bacteriocin production by five strains of Lactococcus lactis isolated from semihard homemade cheese. Can. J. Microbiol. 52, 1110-1120. doi: 10.1139/w06-072

Kojic, M., Strahinic, I., and Topisirovic, L. (2005). Proteinase PI and lactococcin A genes are located on the largest plasmid in Lactococcus lactis subsp. lactis bv. diacetylactis S50. Can. J. Microbiol. 51, 305-314. doi: 10.1139/w05-009

Laan, H., and Konings, W. N. (1989). Mechanism of proteinase release from Lactococcus lactis subsp. cremoris Wg2. Appl. Environ. Microbiol. 55, 3101-3106.

Lahtinen, S., Arthur, C. O., Sepo, S., and Atte von, W. (eds). (2012). Lactic Acid Bacteria: Microbiological and Functional Aspects. London: CRC Press.

Lasta, S., Fajloun, Z., Mansuelle, P., Sabatier, J. M., Boudabous, A., and Sampieri, F. (2008). Chemical synthesis of lactococcin B and functional evaluation of the Nterminal domain using a truncated synthetic analogue. Arch. Inst. Pasteur Tunis 85, 9-19.

Law, J., Buist, G., Haandrikman, A., Kok, J., Venema, G., and Leenhouts, K. (1995). A system to generate chromosomal mutations in Lactococcus lactis which allows fast analysis of targeted genes. J. Bacteriol. 177, 7011-7018.

Lozo, J., Vukasinovic, M., Strahinic, I., and Topisirovic, L. (2004). Characterization and antimicrobial activity of bacteriocin 217 produced by natural isolate Lactobacillus paracasei subsp. paracasei BGBUK2-16. J. Food Prot. 67, 2727-2734.

Maguin, E., Duwat, P., Hege, T., Ehrlich, D., and Gruss, A. (1992). New thermosensitive plasmid for gram-positive bacteria. J. Bacteriol. 174, 5633-5638.

Maguin, E., Prévost, H., Ehrlich, S. D., and Gruss, A. (1996). Efficient insertional mutagenesis in lactococci and other gram-positive bacteria. J. Bacteriol. 178, 931-935.

Marugg, J. D., Meijer, W., van Kranenburg, R., Laverman, P., Bruinenberg, P. G., and de Vos, W. M. (1995). Medium-dependent regulation of proteinase gene expression in Lactococcus lactis: control of transcription initiation by specific dipeptides. J. Bacteriol. 177, 2982-2989.

Meijerink, M., and Wells, J. M. (2010). Probiotic modulation of dendritic cells and $\mathrm{T}$ cell responses in the intestine. Benef. Microbes 1, 317-326. doi: 10.3920/BM2010.0029
Mierau, I., and Kleerebezem, M. (2005). 10 years of the nisin-controlled gene expression system (NICE) in Lactococcus lactis. Appl. Microbiol. Biotechnol. 68, 705-717. doi: 10.1007/s00253-005-0107-6

Miladinov, N., Kojic, M., Arsenijevic, S., Lozo, J., and Topisirovic, L. (2001). Characterization of natural isolate Lactococcus lactis subsp. lactis BGIS29, a strain producing bacteriocin IS29 and cell wall-associated proteinase. Arch. Biol. Sci. 53, 7-16.

Miller, H. J. (1972). Experiments in Molecular Genetics. New York: Cold Spring Harbor Laboratory.

Nawrocki, K., Crispell, E., and McBride, S. (2014). Antimicrobial peptide resistance mechanisms of gram-positive bacteria. Antibiotics 3, 461-492. doi: 10.3390/antibiotics3040461

O'sullivan, D. J., and Klaenhammer, T. R. (1993). Rapid mini-prep isolation of high-quality plasmid DNA from Lactococcus and Lactobacillus spp. Appl. Environ. Microbiol. 59, 2730-2733.

Roces, C., Pérez, V., Campelo, A. B., Blanco, D., Kok, J., Kuipers, O. P., et al. (2012). The putative lactococcal extracytoplasmic function anti-sigma factor llmg2447 determines resistance to the cell wall-active bacteriocin lcn972. Antimicrob. Agents Chemother. 56, 5520-5527. doi: 10.1128/AAC.01206-12

van Belkum, M. J., Kok, J., Venema, G., Holo, H., Nes, I. F., Konings, W. N., et al. (1991). The bacteriocin lactococcin A specifically increases permeability of lactococcal cytoplasmic membranes in a voltage-independent, protein-mediated manner. J. Bacteriol. 173, 7934-7941.

van Hemert, S., Meijerink, M., Molenaar, D., Bron, P. A., de Vos, P., Kleerebezem, M., et al. (2010). Identification of Lactobacillus plantarum genes modulating the cytokine response of human peripheral blood mononuclear cells. BMC Microbiol. 10:293. doi: 10.1186/1471-2180-10-293

Venema, K., Abee, T., Haandrikman, A. J., Leenhouts, K. J., Kok, J., Konings, W. N., et al. (1993). Mode of action of lactococcin B, a thiol-activated bacteriocin from Lactococcus lactis. Appl. Environ. Microbiol. 59, 1041-1048.

Venema, K., Chikindas, M. L., Seegers, J., Haandrikman, A. J., Leenhouts, K. J., Venema, G., et al. (1997). Rapid and efficient purification method for small, hydrophobic, cationic bacteriocins: purification of lactococcin $\mathrm{B}$ and pediocin PA-1. Appl. Environ. Microbiol. 63, 305-309.

Venema, K., Dost, M. H., Venema, G., and Kok, J. (1996). Mutational analysis and chemical modification of Cys 24 of lactococcin B, a bacteriocin produced by Lactococcus lactis. Microbiology 142, 2825-2830. doi: 10.1099/13500872-14210-2825

Conflict of Interest Statement: The authors declare that the research was conducted in the absence of any commercial or financial relationships that could be construed as a potential conflict of interest.

Received: 18 November 2014; accepted: 25 January 2015; published online: 10 February 2015.

Citation: Vukotic G, Mirkovic N, Jovcic B, Miljkovic M, Strahinic I, Fira D, Radulovic Z and Kojic M (2015) Proteinase PrtP impairs lactococcin LcnB activity in Lactococcus lactis BGMN1-501: new insights into bacteriocin regulation. Front. Microbiol. 6:92. doi: $10.3389 /$ fmicb.2015.00092

This article was submitted to Food Microbiology, a section of the journal Frontiers in Microbiology.

Copyright (c) 2015 Vukotic, Mirkovic, Jovcic, Miljkovic, Strahinic, Fira, Radulovic and Kojic. This is an open-access article distributed under the terms of the Creative Commons Attribution License (CC BY). The use, distribution or reproduction in other forums is permitted, provided the original author(s) or licensor are credited and that the original publication in this journal is cited, in accordance with accepted academic practice. No use, distribution or reproduction is permitted which does not comply with these terms. 